\title{
PROSPEK USAHA MEUBEL KAYU DI KECAMATAN ARGA MAKMUR
}

\author{
Dian Mardiati Sari \\ Universitas Dehasen Bengkulu \\ Dian_Kicky@yahoo.co.id
}

\begin{abstract}
ABSTRAK
Dian Mardiati Sari; Tujuan dalam penelitian ini adalah untuk mengetahui dan menganalisis prospek usaha meubel kayu di Kecamatan Arga Makmur. Penelitian ini menggunakan analisis deskriptif. Hasil penelitian ini adalah lamanya usaha yang dijalankan unit usaha meubel kayu di Kecamatan Arga Makmur rata-rata antara 10-15 tahun yaitu sebesar 60\%. Rata-rata jumlah tenaga kerjanya yang dimiliki oleh tiap unit usaha meubel kayu di Kecamatan Arga Makmur rata-rata antara 1-3 tenaga kerja yaitu sebanyak 19 unit usaha atau berkisar 63.3\%. Besarnya modal yang dikeluarkan oleh usaha meubel kayu di Kecamatan Arga Makmur Rp 10.000.000,- dengan omset penjualan hasil produksi usaha meubel kayu bekisar Rp 10.000.000,- s/d Rp 15.000.000,- per bulannya. Para pengusaha menerima pendapatan berkisar antara Rp 2.000.000,- s/d Rp 3.000.000,- setiap bulannya. Selain itu, usaha meubel kayu di Kecamatan Arga Makmur juga mampu membuka lapangan usaha dan menyerap tenaga kerja. Kendala-kendala yang dihadapi oleh usaha meubel kayu adalah kurangnya tingkat pendidikan pengusaha dan tenaga kerja, kurangnya sarana dan prasarana pasar, minimnya teknologi yang digunakan. Pengelolahan usaha meubel kayu di kecamatan Arga Makmur masih sederhana. Namun demikian, usaha meubel kayu di Kecamatan Arga Makmur mampu memberikan keuntungan yang baik kepada pengusaha dan mampu meningkatkan pembangunan ekonomi daerah. Peluang usaha akan menjadikan lebih baik lagi apabila kendala-kendala yang dihadapi dalam menjalankan usaha mampu diatasi dengan baik.
\end{abstract}

\section{ABSTRACT}

Dian Mardiati Sari; The aim in this study was to determine and analyze the wooden furniture business prospects in Sub Arga Makmur. This research using descriptive analysis. Results of this research is the length of a business carried on in the wooden furniture business unit Arga Makmur District of average between 10 15 years, namely by 60\%. The average amount of labor which is owned by each business unit wooden furniture in Arga Makmur District of average between 1-3 labor as many as 19 business units or about 63.3\%. The amount of capital spent by the wooden furniture business in Arga Makmur District of Rp 10,000,000, - with a business turnover of wood furniture production bekisar $R p$ 10,000,000, - $s / d R p$

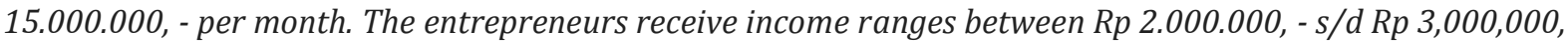
- per month. In addition, the wooden furniture business in District Arga Makmur is also able to open the field of business and labor intensive. Constraints faced by businesses wood furniture is a lack of education employers and labor, the lack of market infrastructure, lack of technology used. Pengelolahan wood furniture businesses in the district Arga Makmur still simple. However, the wooden furniture business in Sub Arga Makmur able to provide considerable benefits to employers and can increase local economic development. Business opportunities will be made better if the constraints faced in running a business is able to overcome with good.

\section{Key Words: Business Prospect, Employment, Capital}

\section{PENDAHULUAN}

Pada hakekatnya pembangunan ekonomi bertujuan untuk mensejahterakan masyarakat. Pembangunan ekonomi diartikan sebagai serangkaian usaha dalam suatu perekonomian untuk mengembangkan kegiatan ekonominya sehingga infrastruktur lebih banyak tersedia, perusahaan semakin banyak dan semakin berkembang, taraf pendidikan semakin tinggi dan teknologi semakin meningkat.

Kabupaten Bengkulu Utara merupakan salah satu kabupaten berkembang yang meningkatkan perkembangan ekonomi daerahnya. Semenjak dikeluarkan undang-undang otonomi daerah nomor 22 tahun 1999 tentang pemerintah daerah yang direvisis menjadi undang-undang nomor 32 tahun 2004 tentang pemerintah daerah, mengharuskan pemerintah daerahnya untuk mengembangkan sendiri sektor-sektor penggerak potensi daerah dan menciptakan kebijakan-kebijakan konomi yang mampu meningkatkan perekonomian daerah. 
Usaha kecil dan menengah merupakan salah satu sektor penggerak pembangunan dan potensi ekonomi daerah berkembang seperti Kabupaten Bengkulu utara. Selain mampu menciptakan nilai tambah dan lapangan usaha, usaha kecil dan menengah juga banyak menyerap tenaga kerja. Usaha kecil dan menengah yang utama dan banyak dikembangkan di Kabupaten Bengkulu Utara adalah baik usaha formal maupun usaha non formal.

Dibawah ini dapat dilihat jumlah tenaga kerja dan nilai tambah pendapatan usaha formal dan non formal Kabupaten Bengkulu Utara selama tiga tahun terakhir yaitu tahun 2011-2013:

Tabel 1 Jumlah Tenaga Kerja dan Nilai Tambah Usaha Formal dan Non Formal Kabupaten Bengkulu Utara Tahun 2011-2013

\begin{tabular}{|c|c|c|c|c|c|c|}
\hline \multirow{2}{*}{ Tahun } & \multicolumn{3}{|c|}{ Usaha Formal } & \multicolumn{3}{|c|}{ Usaha Non Formal } \\
\cline { 2 - 7 } & $\begin{array}{c}\text { Unit } \\
\text { Usaha }\end{array}$ & $\begin{array}{c}\text { Tenaga } \\
\text { Kerja }\end{array}$ & Nilai Tambah & $\begin{array}{c}\text { Unit } \\
\text { Usaha }\end{array}$ & $\begin{array}{c}\text { Tenaga } \\
\text { Kerja }\end{array}$ & Nilai Tambah \\
\hline 2011 & 250 & 488 & 41.780 .000 .000 & 658 & 337 & 40.580 .000 .000 \\
\hline 2012 & 254 & 513 & 42.395 .060 .000 & 601 & 342 & 41.460 .641 .500 \\
\hline 2013 & 265 & 530 & 42.600 .000 .000 & 608 & 350 & 41.740 .500 .000 \\
\hline
\end{tabular}

Sumber : Dinas Koperasi, UKM, Perindustrian dan Perdagangan Kecamatan Arga Makmur

Berdasarkan tabel 1 di atas dapat dilihat bahwa jumlah usaha industry, tenaga kerja dan nilai tambah usaha formal dan non formal Kabupaten Bengkulu Utara meningkat dari tahun 2011-2013. Apabila dibandingkan dari sisi tenaga kerja, usaha formallebih banyak menyerap tenaga kerja dibandingkan usaha non formal dan hal ini juga berlaku untuk nilai tambah, sedangkan dilihat dari sisi jumlah unit usaha non formal lebih banyak dibandingkan usaha formal.

Di Kabupaten Bengkulu Utara, Kecamatan Arga Makmur merupakan Kecamatan yang memiliki banyak usaha kecil dan menengah. Adapun data usaha kecil dan menengah formal Kecamatan Arga Makmur dapat dilihat dari Tabel 2.1 dibawah ini:

Tabel 2 Usaha kecil dan menengah formal Kecamatan Arga Makmur menurut jenisnya tahun 2012

\begin{tabular}{|c|l|c|}
\hline No & \multicolumn{1}{|c|}{ Jenis Usaha Formal } & Unit Usaha (Unit) \\
\hline 1 & Usaha Meubel Kayu & 30 \\
\hline 2 & Usaha Meubel Rotan & 1 \\
\hline 3 & Usaha Kerajinan Bambu & 13 \\
\hline 4 & Usaha Kayu Gergajian & 22 \\
\hline 5 & Bengkel & 8 \\
\hline 6 & Percetakan dan Sablon & 14 \\
\hline 7 & Penjahit dan Konveksi & 1 \\
\hline 8 & Batako & 2 \\
\hline 9 & Industri Barang dari Semen & 6 \\
\hline 10 & Penggilingan Padi & 7 \\
\hline 11 & Industri Makanan Ringan & 16 \\
\hline 12 & Industri Tahu Tempe & 7 \\
\hline 13 & Industri Kopi Bubuk & 19 \\
\hline 14 & Jenis Usaha Lainnya & \\
\hline & & \\
\hline
\end{tabular}

Sumber : Dinas Koperasi, UKM, Perindustrian dan Perdagangan Kecamatan Arga Makmur

Berdasarkan Tabel 2 diatas dapat dilihat pada tahun 2012 jumlah unit usaha formal Kecamatan Arga Makmur berjumlah 162 unit usaha. Usaha yang memiliki unit usaha paling banyak adalah usaha meubel kayu yaitu sebanyak 30 unit, sedangkan usaha yang paling sedikit adalah usaha industri kerajinan batako yaitu sebanyak 1 unit.

Perkembangan usaha, khususnya usaha Meubel Kayu di Kecamatan Arga Makmur cenderung meningkat setiap tahunnya. Perkembangan ini seiring dengan aktivitas ekonomi dan peningkatan kebutuhan masyarakat akan perlengkapan rumah tangga.

Sekalipun perkembangan usaha meubel kayu ini baik, namun usaha meubel kayu di Kecamatan Arga Makmur ini tidak terlepas dari permasalahan-permasalahan, dengan munculnya usaha baru yang tidak terdaftar tentu membuat situasi kurang menguntungkan bagi usaha yang resmi. Untuk itu, diperlukan koordinasi dari banyak pihak dan mempertimbangkan banyak kriteria serta perhitungan yang tepat dalam pengambilan keputusan, agar prospek ke depan usaha meubel kayu di Kecamatan Arga Makmur menjadi lebih baik. 


\section{LANDASAN TEORI}

\section{Usaha}

Usaha adalah suatu kegiatan yang menghasilkan barang dengan tujuan untuk dijual baik seluruhnya atau sebagian serta ada seorang atau lebih yang bertanggung jawab atas resiko usaha (BPS,2004). Usaha atau dapat juga disebut suatu perusahaan, yaitu suatu bentuk usaha yang melakukan kegiatan secara tetap dan terus menerus dengan tujuan memperoleh keuntungan, baik yang diselenggarakan oleh perorangan maupun badan usaha yang berbentuk badan hokum atau tidak berbentuk badan hokum, yang didirikan dan berkedudukan di suatu daerah dalam suatu Negara.

Jenis usaha yang memiliki peranan yang penting dalam suatu Negara dan daerah berkembang adalah usaha skala mikro dan kecil. Yaitu memiliki peranan penting sebagai sumber utama lapangan pekerjaan dan pendapatan (Arsyad,2008). Usaha kecil berdasarkan Undang-Undang Nomor 20 tahun 2008, didefinisikan sebagai usaha ekonomi produktif yang berdiri sendiri, yang dilakukan orang perorangan atau badan usaha yang bukan merupakan anak perusahaan atau bukan cabang perusahaan yang dimiliki, dikuasai, atau menjadi bagian baik langsung maupun tidak langsung dari usaha menengah yang memenuhi kriteria usaha kecil sebagaimana dimaksud dalam undang-undang.

\section{Produksi}

Produksi adalah transformasi atau perubahan menjadi barang produk atau proses dimana masukan (Input) diubah menjadi keluaran (Output). Untuk dapat melakukan proses produksi, maka diperlukan tenaga manusia, sumber-sumber alam, modal dalam segala bentuk, serta kecakapan. Produksi merupakan suatu kegiatan yang mengubah input menjadi output. Kegiatan produksi tersebut di dalam ekonomi dinyatakan dalam fungsi produksi, dimana fungsi tersebut menunjukan jumlah maksimum output yang dihasilkan dari pemakaian sejumlah input dengan menggunakan teknologi tertentu. Agar produksi yang dijalankan dapat menciptakan hasil, maka diperlukan beberapa faktor produksi atau input yang diperlukan di proses secara bersama-sama dalam proses produksi.

Sukirno (2002) menyatakan pengertian produksi lainnya yaitu sebagai hasil dari proses atau aktivitas ekonomi dengan memanfaatkan beberapa masukan atau input. Dengan pengertian ini dapat dipahami bahwa kegiatan produksi diartikan sebagai aktivitas dalam menghasilkan output dengan menggunakan teknik produksi tertentu untuk mengelola atau memproses input sedemikian rupa. Faktorfaktor produksi dikenal pula dengan istilah input dan jumlah produksi selalu juga disebut sebagai output. Fungsi produksi selalu dinyatakan dengan rumus,

$$
\begin{aligned}
& \mathrm{Q}=\mathrm{f}\{\mathrm{K}, \mathrm{L}, \mathrm{R}, \mathrm{T}\} \\
& \text { Dimana, } \\
& \mathrm{K}=\text { Modal } \\
& \mathrm{L}=\text { Tenaga Kerja } \\
& \mathrm{R}=\text { Sumber Daya Alam } \\
& \mathrm{T}=\text { Teknologi }
\end{aligned}
$$

Menurut Aziz N (2003), teori produksi dapat dibedakan menjadi dua bagian yaitu yang pertama, teori produksi jangka pendek dimana apabila seorang produsen menggunakan faktor produksi maka ada variabel yang bersifat tetap. Kedua, teori produksi jangka panjang apabila semua input variabel dan tidak terdapat variabel input tetap. Sehingga dapat diasumsikan bahwa ada dua jenis faktor produksi yaitu tenaga kerja (TK) dan modal (M). sedangkan produksi adalah suatu proses dimana beberapa barang dan jasa yang disebut input diubah menjadi barang dan jasa lain yang disebut output. Banyak jenis aktivasi yang terjadi dalam proses produksi, meliputi perubahan bentuk, tempat, waktu, dan penggunaan hasilhasil produksi. Sehingga dapat dikatakan bahwa output suatu usaha yang berupa barang-barang produksi tergantung pada jumlah input yang digunakan dalam proses produksi, dan tenaga kerja beserta modal merupakan faktor yang penting dalam suatu produksi.

\section{Tenaga Kerja}

Tenaga kerja dalam pembangunan merupakan faktor yang potensial bagi pembangunan secara keseluruhan. Tenaga kerja adalah daya manusia untuk melakukan pekerjaan. Pengertian umu tersebut sesuai pengertian tenaga kerja yang dimuat dalam undang-undang pokok ketenaga kerjaan No.41 tahun 1990, yaitu setiap orang yang mampu melakukan pekerjaan baik di dalam maupun di luar hubungan kerja duna menghasilkan jasa atau barang untuk memenuhi kebutuhan masyarakat (Sumarsono, 2009).

Tenaga kerja adalah penduduk pada usia kerja yaitu antara 15 tahun sampai dengan 64 tahun. Penduduk dalam usia kerja dapat dibedakan menjadi dua golongan yaitu angkatan kerja (labor force) dan bukan angkatan kerja (Irawan dkk, 2002). Tenaga kerja adalah semua orang yang bersedia dan sanggup bekerja, termasuk mereka yang menganggur meskipun bersedia dan sanggup bekerja dan mereka yang 
menganggur terpaksa akibat tidak ada kesempatan kerja. Untuk menggolongkan penduduk dalam golongan tenaga kerja atau bukan tenaga kerja, dapat dilihat dari kemampuan seseorang untuk melakukan suatu pekerjaan. Semua penduduk yang memiliki kemampuan untuk melakukan aktivitas bekerja dapat digolongkan dalam kelompok tenaga kerja.

Selain pendudu yang sudah bekerja atau sedang bekerja, serta penduduk yang sedang mencari pekerjaan, maka penduduk yang melakukan kegiatan lain seperti bersekolah atau mengurus rumah tangga pun termasuk dalam kelompok tenaga kerja Karena mampu melakukan suatu pekerjaan. Penduduk bersekolah dan mengurus rumah tangga walaupun tidak sedang bekerja, tetapi mereka secara fisik mampu bekerja dan sewaktu-waktu dapat untuk ikut bekerja. Sehingga mereka dapat digolongkan kedalam kelompok tenaga kerja karena memang memiliki kemampuan untuk bekerja serta memiliki potensi untuk bekerja disaat mereka ingin melakukannya (Simanjuntak,2005)

Selanjutnya Sumarsono (2009) menyebutkan bahwa tenaga kerja atau sumber daya manusia (SDM) adalh menyangkut manusia yang mampu bekerja untuk memberikan jasa atau usaha kerja tersebut. Mampu bekerja yang dimaksud adalah mampu melakukan kegiatan yang mempunyai nilai ekonomis, yaitu suatu kegiatan yang menghasilkan barang dan jasa untuk memenuhi kebutuhan masyarakat. Pada umumnya, secara fisik kemampuan bekerja diukur dengan usia. Sehingga orang yang dalam usia kerja dianggap mampu bekerja. Dari beberapa pengertian diatas dapat disimpulkan bahwa tenaga kerja adalah total penduduk dalam usia produktif yang dapat melakukan suatu pekerjaan baik yang sudah bekerja, sedang mencari pekerjaan, maupun yang tidak bekerja dan melakukan kegiatan selain bekerja. Dengan demikian tenaga kerja merupakan salah satu faktor produksi yang penting bagi setiap kegiatan produktif.

\section{Modal}

Untuk mendirikan atau menjalankan suatu usaha maka diperlukan sejumlah modal (uang) dan tenaga (Keahlian). Modal adalah bentuk uang diperlukan untuk membiayai segala keperluan usaha mulai dari biaya pra investasi, pengurusan izin, biaya investasi untuk pembelian aktiva tetap, sampai modal kerja. Sementara itu, modal keahlian adalah keahlian dan kemampuan seseorang untuk mengelola atau menjalankan suatu usaha (Kasmir,2011). Modal adalah dana yang digunakan dalam proses produksi memproduksi barang dan jasa tidak termasuk nilai tanah dan bangunan yang ditempati atau biasa disebut dengan modal kerja.

Faktor modal adalah salah satu faktor yang diperlukan dalam operasional proses produksi untuk menghasilkan barang atau jasa untuk meningkatkan pendapatan. Masalah modal sering kali disoroti sebagai salah satu faktor utama penghambat produksi dan dengan demikian juga penggunaan tenaga kerja. Modal juga bias dilakukan dengan investasi. Investasi dapat diartikan sebagai pengeluaran atau pembelanjaan penanaman-penanaman modal atau perusahaan untuk membeli barang-barang modal dan perlengkapan-perlengkapan produksi untuk menambah kemampuan memproduksi barang-barang dan jasa-jasa yang tersedia dalam perekonomian. Mesin digerakkan oleh tenaga kerja atau sumber-sumber serta bahan-bahan dikelola oleh manusia. Definisi investasi dapat lebih dipertajam sebagai pengeluaranpengeluaran yang meningkatkan stok barang modal (capital stock). Umumnya stok barang modal dinilai dengan uang yaitu jumlah barang modal dikalikan harga perolehan per unit barang modal. Dengan demikian barang modal merupakan konsep stok, karena besarnya dihitung pada suatu periode tertentu (Rahardja dkk,2004).

Salah satu cara untuk meningkatkan keuntungan usaha adalah dengan meningkatkan jumlah produksi. Dengan menambah jumlah modal yang ada, maka suatu perusahaan mampu meningkatkan jumlah output atau umlah produksinya (Bangun,2010). Meningkatnya jumlah output suatu usaha dalam proses produksi maka dapat meningkatkan jumlah pendapatan yang diterima oleh pengusaha. Maka dapat disimpulkan bahw jumlah modal yang digunakan dalam suatu proses produksi dapat mempengaruhi tingkat pendapatan yang diterima oleh pengusaha.

Modal juga ada yang disebut human capital atau modal manusia yaitu modal non fisik yang melekat pada diri seorang pekerja dimana modal ini mempengaruhi kualitas seorang tenaga kerja. Modal tersebut berupa tingkat pendidikan, tingkat keterampilan, serta tingkat kesehatan. Secara ekonometrika hubungan antara tingkat pendidikan dan tingkat pendapatan dijelaskan oleh persamaan mincer yaitu semakin tinggi tingkat pendidikan dan tingkat pengalaman maka semakin tinggi tingkat pendapatan begitu pula sebaliknya. Namun untuk pengaruh pengalaman bersifat non linier. Secara spesifik, pendidikan mempengaruhi produktivitas dan kualitas tenaga kerja (Santoso,2012).

\section{Pendapatan}

Pendapatan adalah seluruh penerimaan yang diterima oleh rumah tangga atau perusahaan atas penjualan barang dan jasa (Asfia dan Lia,2012). Pengertian lain dari pendapatan adalah seluruh 
penerimaan penghasilan yang diterima seseorang yang bekerja dengan status bekerja sendiri (Winardi,2001). Dalam mengukur kondisi ekonomi seseorang atau rumah tangga suatu usaha, salah satu konsep yang paling sering digunakan adalah tingkat pendapatan. Pendapatan dapat menunjukkan seluruh uang atau seluruh material lainnya yang dapat dicapai dari penggunaan kekayaan yang diterima oleh seseorang, rumah tangga, atat usaha tertentu.

Pendapatan merupakan faktor dalam menjalankan kebutuhan sehari-hari. Segala aktifitas dalam rumah tangga atau usaha berusaha keras agar kebutuhan keluarga. Setiap rumah tangga berkisar pada pemenuhan kebutuhan keluarga. Setiap rumah tangga atau usaha berusaha keras agar kebutuhan hidupnya dapat terpenuhi secara maksimal. Dimana dalam teori ekonomi dikatakan bahwa pendapatan selalu menimbulkan perubahan keatas permintaan berbagai jenis barang (Sukrno,2012). Pendapatan juga dapat diartikan sebagai pendapatan bersih seseorang baik berupa uang atau netura. Secara umum pendapatan dapat digolongkan menjadi tiga bagian, yaitu: a. gaji, merupakan suatu imbalan yang diperoleh seseorang setelah melakukan suatu pekerjaan. b. pendapatan dari kekayaan, merupakan nilai total produksi dikurangi dengan biaya yang dikeluarkan baik dalam bentuk uang atau lainnya. c. pendapatan dari sumber lain.

Pendapatan merupakan sumber utama dalam berbagai kegiatan ekonomi yang dilakukan oleh masyarakat. Semua kebutuhan akan barang maupun jasa dapat terpenuhi dengan adanya pendapatan. Seseorang yang mempunyai pendapatan dan kekayaan akan cenderung lebih memilih barang atau jasa yang akan dikonsumsinya. Pendapatan dalam suatu rumah tangga merupakan salah satu faktor yang dominan dalam pemenuhan dan pemuasan kebutuhan sehari-hari. Semakin tinggi tingkat pendapatan rumah tangga, semakin banyak kebutuhan rumah tangga tersebut dapat terpenuhi.

\section{Kerangka Analisis}

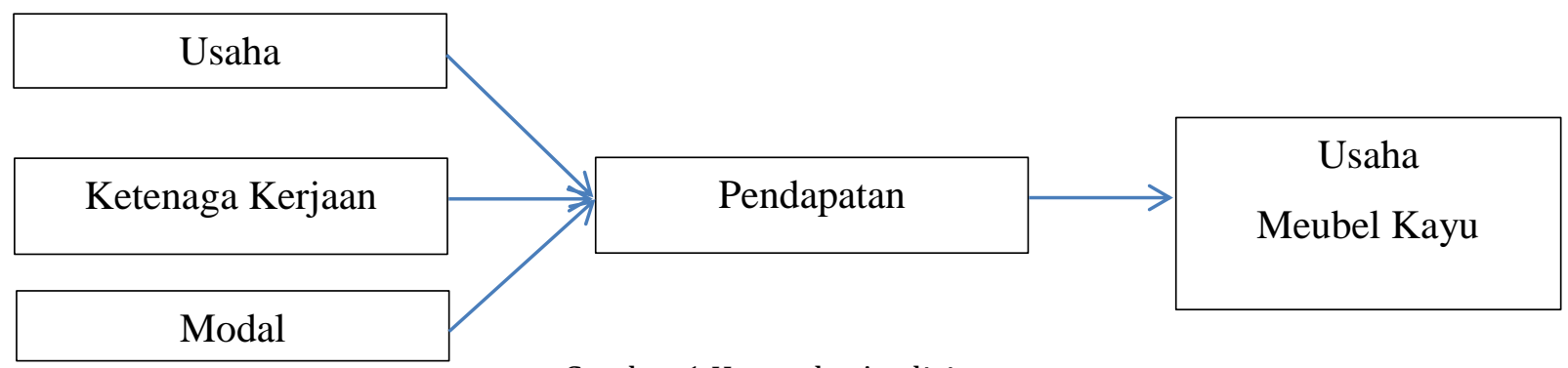

Gambar 1.Kerangka Analisis

\section{HASIL DAN PEMBAHASAN}

Responden dalam penelitian ini, pengusaha usaha meubel kayu di Kecamatan Arga Makmur sebanyak 30 Usaha. Rincian karakteristik meliputi: Manajemen Usaha, Tenaga Kerja, dan Keuangan Usaha Meubel Kayu di Kecamatan Arga Makmur. Dari hasil penelitianyang dilakukan dengan kuisioner dan wawancara langsung kepada responden diperoleh karakteristik usaha meubel kayu di Kecamatan Arga Makmur.

\section{Karakteristik Responden Menurut Umur}

Dalam penelitian ini umur pemilik usaha meubel kayu berkisaran antara 30 tahun hingga 50 tahun, maka dapat dikelompokan sebagai berikut :

Tabel 3 Responden dilihat dari umur

\begin{tabular}{|c|c|c|c|}
\hline No & Karakteristik Responden & Jumlah (Orang) & Presentase $(\%)$ \\
\hline 1 & $30-35$ tahun & 5 & 16.7 \\
\hline 2 & $36-40$ tahun & 17 & 56.7 \\
\hline 3 & 41-50 tahun & 8 & 26.7 \\
\hline & Jumlah & 30 & 100.0 \\
\hline
\end{tabular}

Sumber : Hasil Penelitian

Dari tabel 3 menunjukkan bahwa bahwa rata-rata responden atau pemilik usaha meubel kayu di Kecamatan Arga Makmur berusia antara 36-45 tahun sebanyak 17 orang atau 56.7 \%.

Karakteristik Responden Menurut Tingkat Pendidikan

Dapat dilihat bahwa tingkat pendidikan formal yang ditempuh oleh pemilik usaha meubel kayu di Kecamatan Arga Makmur dapat di kelompokan menjadi 3 tingkatan yaitu, SMP, SMA, Diploma (D3)/ S1 
(Perguruan Tinggi). Berdasarkan data responden menurut tingkat pendidikan yang diperoleh di daerah penelitian sebagai berikut:

Tabel 4 Respondendilihat dari tingkat pendidikan

\begin{tabular}{|c|c|c|c|}
\hline No & Jenjang Pendidikan & Jumlah (Orang) & Presentase (\%) \\
\hline 1 & SMP & 2 & 6.7 \\
\hline 2 & SMA & 27 & 90.0 \\
\hline 3 & D3/S1 & 1 & 3.3 \\
\hline & Jumlah & 30 & 100.0 \\
\hline
\end{tabular}

\section{Sumber : Hasil Penelitian}

Dari tabel 4 menunjukan bahwa responden rata-rata pemilik usaha meubel kayu di Kecamatan Arga Makmur berpendidikan terakhirnya adalah pada jenjang SMA sebanyak 27 orang atau 90\%, sehingga pada tingkat pendidikan tersebut responden sudah cukup mampu dalam menanggapi atau menjalankan usaha meubel kayu di Kecamatan Arga Makmur.

\section{Karakteristik Responden Menurut Lamanya Usaha}

Karakteristik responden menurut lamanya usaha pada penelitian ini menjelaskan data mengenai lamanya usaha yang dijalankan pada usaha meubel kayu di Kecamatan Arga Makmur yang disajikan pada tabel dibawah ini :

Tabel 5 Responden Menurut Lamanya Usaha

\begin{tabular}{|c|c|c|c|}
\hline No & Lama Usaha & Jumlah (Orang) & Presentase (\%) \\
\hline 1 & $10-15$ tahun & 18 & 60.0 \\
\hline 2 & 16-20 tahun & 10 & 33.3 \\
\hline 3 & $>20$ tahun & 2 & 6.7 \\
\hline & Jumlah & 30 & 100.0 \\
\hline
\end{tabular}

Sumber : Hasil Penelitian

Dari tabel 5 menunjukan bahwa dalam jangka waktu 10-15 tahun terakhir banyak bermunculan usaha meubel kayu di Kecamatan Arga Makmur sebanyak 18 responden atau 60\%, sehingga dapat dikatakan usaha meubel kayu meningkat dalam 10 tahun terakhir.

\section{Karakteristik Responden Menurut Status Kepemilikan Tempat Usaha}

Karekteristik responden menurut status kepemilikan tempat usaha dalam penelitian ini dikelompokkan menjadi 2 yaitu: milik sendiri dan sewa.

Tabel 6 Responden Menurut Status Kepemilikan Tempat Usaha

\begin{tabular}{|c|c|c|c|}
\hline No & Status Tempat Usaha & Jumlah (Orang) & Presentase (\%) \\
\hline 1 & Milik Sendiri & 30 & 100.0 \\
\hline 2 & Sewa & 0 & 0.0 \\
\hline \multicolumn{2}{|r|}{ Jumlah } & 30 & 100.0 \\
\hline
\end{tabular}

Sumber : Hasil Penelitian

Dari tabel 6 dapat diketahui bahwa tempat usaha seluruh responden yang diteliti berstatus milik sendiri dalam menjalankan usaha meubel kayu di Kecamatan Arga Makmur. Berdasarkan hasil observasi tempat usaha yang dimiliki para responden rata-rata berada di lingkungan atau dipekarangan rumah mereka sendiri.

\section{Karakteristik Responden Menurut Ketenagakerjaan}

Jumlah tenaga kerja pada penelitian ini merupakan jumlah seluruh tenaga kerja yang digunakan pada tiap usaha meubel kayu, dikelompokan menjadi 3 kelompok, yaitu: 1-3 orang, 4-6 orang, dan > 7 orang.

Tabel 7 Responden Menurut Jumlah Tenaga Kerja

\begin{tabular}{|c|c|c|c|}
\hline No & Tenaga Kerja & Jumlah (Orang) & Presentase (\%) \\
\hline 1 & $1-3$ & 19 & 63.3 \\
\hline 2 & $4-6$ & 6 & 20.0 \\
\hline 3 & $>7$ & 5 & 16.7 \\
\hline \multicolumn{2}{|c|}{ Jumlah } & 30 & 100.0 \\
\hline
\end{tabular}

Sumber : Hasil Penelitian 
Dari tabel 7 dapat diketahui bahwa rata-rata jumlah tenaga kerja yang digunakan pada usaha meubel kayu di Kecamatan Arga Makmur berkisar antara 1-3 orang, berdasarkan hasil wawancara maka diketahui bahwa mayoritas pendidikan tenaga kerja yang digunakan adalah tamatan SMA dan SMP. Sistem upah yang diberikan kepada tenaga kerja berbeda-beda sesuai dengan pekerjaan yang mereka jalankan.

\section{Karakteristik Responden Menurut Modal Usaha}

Responden menurut modal usaha dapat dilihat di bawah ini.

Tabel 8 Responden Menurut Modal Usaha

\begin{tabular}{|c|c|c|c|}
\hline No & Asal Modal & Jumlah (Orang) & Presentase (\%) \\
\hline 1 & Modal Sendiri & 26 & 86.7 \\
\hline 2 & Bantuan Modal & 0 & 0 \\
\hline 3 & Pinjaman & 4 & 13.3 \\
\hline \multicolumn{2}{|c|}{ Jumlah } & 30 & 100.0 \\
\hline
\end{tabular}

Sumber : Hasil Penelitian

Dari tabel 8 diketahui bahwa sumber modal yang diperoleh responden berasal dari modal sendiri yaitu sebanyak 26 unit usaha atau berkisar 86.7\%, sedangkan 4 unit usaha atau sebesar 13.3\% modalnya berasal dari pinjaman koperasi atau perbankkan, dan tidak ada unit-unit usaha yang modal usahanya berasal bantuan modal dari rekan kerja. Pinjaman yang berasal dari koperasi dan perbankkan, unit usaha mengembalikan secara mengansur setiap bulannya ditambahn dengan bunga pinjaman sesuai dengan perjanjian dengan pihak koperasi dan perbankan waktu mengajukan pinjaman.

Karakteristik Responden Menurut Besar Omset Penjualan

Responden menurut jumlah omset penjualan usaha meubel kayu dapat dilihat dibawah ini.

Tabel 9 Responden Menurut Besar Omset Penjualan

\begin{tabular}{|c|c|c|c|}
\hline No & Besarnya Omset & Unit Usaha & Presentase (\%) \\
\hline 1 & $\operatorname{Rp~} 10.000 .000,-\mathrm{s} / \mathrm{d}$ Rp 15.000.000,- & 20 & 66,7 \\
\hline 2 & $\mathrm{Rp} 16.000 .000,-\mathrm{s} / \mathrm{d}$ Rp 20.000.000,- & 6 & 13,3 \\
\hline 3 & $>$ Rp 21.000.000,- & 4 & 100.0 \\
\hline \multicolumn{2}{|c|}{ Jumlah } & 30 & \\
\hline
\end{tabular}

Sumber : Hasil Penelitian

Dari tabel 9 diketahui bahwa omset penjualan yang diperoleh responden kisaran antara Rp 10.000.000,s/d Rp 15.000.000,- sebanyak 20 unit usaha atau bekisar 66.7\%. Besarnya omset penjualan tergantung oleh banyak pesanan atau banyaknya barang yang disorder kepada konsumen atau banyaknya jumlah barang yang diproduksi. Selain itu juga, harga yang ditawarkan disesuaikan dengan besarnya modal yang digunakan dalam proses produksi barang.

\section{Karakteristik Responden Menurut Jumlah Modal yang Dikeluarkan}

Pengeluaran dalam penelitian ini merupakan jumlah pengeluaran yang dikeluarkan usaha meubel kayu Kecamatan Arga Makmur, dapat dilihat dibawah ini.

Tabel 10 Responden Menurut Jumlah Modal Perbulan

\begin{tabular}{|c|c|c|c|}
\hline No & Besarnya Modal yang Dikeluarkan & Unit Usaha & Presentase (\%) \\
\hline 1 & $<$ Rp 10.000.000,- & 15 & 50 \\
\hline 2 & Rp 11.000.000,-s/d Rp 15.000.000,- & 10 & 33.3 \\
\hline 3 & Rp 16.000.000,-s/d Rp 20.000.000,- & 5 & 16.7 \\
\hline & Jumlah & 30 & 100.0 \\
\hline
\end{tabular}

Sumber : Hasil Penelitian

Dari tabel 10 diketahui bahwa besar modal yang dikeluarkan oleh usaha meubel kayu di Kecamatan Arga Makmur setiap bulannya rata-rata adalah berkisar Rp kurang dari Rp 10.000.000,- yaitu dimiliki oleh 15 unit usaha atau sebesar 50\%. Unit usaha yang mengeluarkan modal usaha terbesar adalah usaha yang memilik mengorder pesanan ke konsumen terbanyak dan memiliki modal dan tenaga kerja dalam jumlah banyak dibandingkan dengan usaha meubel kayu yang lain. 


\section{Karakteristik Responden Menurut Jumlah Pendapatan Per Bulan}

Pendapatan dalam penelitian ini merupakan jumlh pendapatan yang diperoleh usaha meubel kayu Kecamatan Arga Makmur, dapat dilihat dibawah ini.

Tabel 11 Responden Menurut Jumlah Pendpatan Perbuln

\begin{tabular}{|c|c|c|c|}
\hline No & Besarnya Pendapatan (Rp) & Unit Usaha & Presentase $(\%)$ \\
\hline 1 & Rp 2.000.000,- s/d Rp 3.000.000,- & 18 & 60 \\
\hline 2 & Rp 4.000.000,- s/d Rp 5.000.000,- & 11 & 36.7 \\
\hline 3 & $>\quad \mathrm{Rp} 6.000 .000,-$ & 1 & 3.3 \\
\hline & Jumlah & 30 & 100.0 \\
\hline
\end{tabular}

Sumber : Hasil Penelitian

Dari tabel 11 diketahui besar pendapatan yang diterima oleh usaha meubel kayu di Kecamatan Arga Makmur rata-rata adalah bekisar Rp 2.000.000,- s/d Rp 3.000.000,- yaitu diperoleh setiap bulannya ada 18 unit usaha, usaha tersebut banyak mengorder pesanan ke konsumen dan memiliki omset penjualan yang besar.

\section{Ketenagakerjaan}

Dari hasil penelitian dapat dilihat bahwa jumlah tenaga kerja yang dimiliki oleh tiap unit usaha industri meubel kayu di Kecamatan Arga Makmur rata-rata antara 1-3 tenaga kerja yaitu sebesar 19 unit usaha, dimana karyawan bekerja harian pada usaha tersebut. Banyaknya tenaga kerja digunakan pada usaha meubel kayu di Kecamatan Arga Makmur juga bergantung pada banyaknya produksi yang dilakukan. Apabila jumlah barang yang diproduksi banyak, maka akan banyak pula jumlah tenaga kerja yang digunakan dalam proses produksinya. Sedangkan apabila sedikit, maka hanya sedikit tenaga kerja yang digunakan. Hal ini mendukung teori ekonoomi yang dijelaskan oleh santosa (2012) yang menunjukan bahwa permintaan akan tenaga kerja merupakan permintaan turunan dari permintaan terhadap barang dan jasa. Artinya banyak sedikitnya jumlah tenaga kerja yang digunakan tergantung pada banyaknya sedikit permintaan terhadap barang dan jasa.

Mayoritas pendidikan tenaga kerja didominasi oleh lulusan SMA dan SMP. Para tenaga kerja tersebut menyatakan lebih memilih untuk bekerja membantu ekonomi keluarga daripada melanjutkan pendidikan ke tingkat yang lebih tinggi. Kurangnya tingkat pendidikan tenaga kerja pada usaha industri meubel kayu berpengaruh pada tingkat kualitas barang yang diproduksi. Lain halnya jika para tenaga kerja merupakan lulusan sarjana desain grafis, tentunya mereka akan mendesain corak, motif, dan bentuk produk dengan menggunakan komputer dan internet sebagai sumber inspirasinya. Keterampilan dalam mengukir meubel juga salah satu faktor pendukung kemajuan usaha, misalnya membuat ukiran yang indah agar mampu menarik konsumen.

Sistem upah para pekerja yang digunakan bervariasi, ada system upah harian da nada juga sistem upah mingguan. Sistem upah pekerja dihitung berdasarkan lamanya proses produksi barang meubel. Semakin besar tingkat keterampilan tenaga kerja dalam menghasilkan barang produksi, maka semakin tinggi upah yang diberikan pengusaha meubel kayu di Kecamatan Arga Makmur kepada tenaga kerjannya. Hubungan dengan penyerapan tenaga kerja, jika dilihat dari hasil penelitian 30 responden diketahui bahwa usaha meubel kayu di Kecamatan Arga Makmur mampu menyerap tenaga kerja kurang lebih sebanyak 100 orang tenaga kerja. Hal ini menunjukan bahwa usaha meubel kayu di Kecamatan Arga Makmur mampu membantu mengurangi tingkat pengangguran dan menciptakan lapangan usaha.

\section{Modal}

Dari hasil penelitian diketahui bahwa sumber modal usaha meubel kayu di Kecamatan Arga Makmur rata-rata berasal dari modal sendiri yaitu sebanyak 26 unit usaha dan sisanya berasal dari pinjaman koperasi serta perbankkan dan tidak ada unit usaha yang modalnya berasal dari bantuan modal dari rekan kerja. Modal yang digunakan merupakan simpanan/ tabungan pengelola usaha atau berasal dari putaran modal sebelumnya. Hal ini menunjukan bahwa rata-rata pengusaha usaha meubel kayu di Kecamatan Arga Makmur menggunakan modal sendiri dan pinjaman untuk membeli barang-barang modal dan perlengkapan-perlengkapan produksi untuk menambah kemapuan memproduksi barangbarang dan jasa-jasa. Penggunaan modal sendiri dalam usaha meubel kayu di Kecamatan Arga Makmur mampu menghindari pengeluaran yang besar untuk membayar bunga pinjaman dan mengalihkan dana tersebut untuk menambah factor produksi lainnya untuk meningkatkan pendapatan atau nilai produksi.

Berdasarkan hasil penelitian dapat dilihat sebagian besar modal yang dikeluarkan oleh usaha meubel kayu di Kecamatan Arga Makmur rata-rata adalah berkisar Rp 10.000.000,- ke bawah. Hal ini menunjukan rata-rata usaha meubel kayu di Kecamatan Arga Makmur mengeluarkan modal usaha berkisar kurang dari Rp 10.000.000,-. Modal usaha meubel kayu di Kecamatan Arga Makmur ini 
digunakan sebagai biaya bahan baku produksi, untuk biaya tenaga kerja, dan biaya lainnya. Usaha yang mengeluarkan modal terbesar adalah usaha meubel kayu yang mengorder pesanan ke konsumen terbanyak dan tenaga kerja dalam jumlah banyak dibandingkan dengan unit usaha yang lainnya.

Besarnya omset penjualan atau nilai produksi usaha meubel kayu di Kecamatan Arga Makmur tergantung oleh besarnya modal yang digunakan, banyak pesanan atau banyaknya barang yang disorder kepada konsumen. Perbedaan harga dapat terjadi dalam proses penjualan barang meubel hasil produksinya, hal ini tergantung pada besarnya modal modal yang dikeluarkan, lama waktu pengerjaan, besar kecil ukuran, serta inovasi barang meubel yang diproduksi. Masih belum adanya pasar khusus dalam menjual hasil produksi membuat pengusaha hanya melakukan produksi barang apabila ada pesanan dari konsumen dan jumlah yang diproduksi juga bergantung pada permintaan konsumen saja.

Selain itu, hasil penelitian juga menunjukkan bahwa rata-rata pendapatan yang diterima oleh usaha meubel kayu di Kecamatan Arga Makmur adalah berkisar antara Rp 2.000.000,- s/d Rp 3.000.000,usaha yang dimiliki pendapatan terbesar adalah unit usaha yang banyak mengorder pesanan ke konsumen atau memproduksi barang dalam jumlah besar. Pendapatan yang diterima oleh pengusaha merupakan pendapatan bersih, dimana omset penjualan hasil produksi sudah dikurangi oleh jumlah modal yang dikeluarkan dalam proses produksi usaha meubel kayu di Kecamatan Arga Makmur. Dari hasil penelitian, dilihat berdasarkan perbandingan antara omset penjualan, modal yang dikeluarkan dan pendapatan, maka dapat disimpulkan bahwa rata-rata usaha meubel kayu di Kecamatan Arga Makmur merupakan usaha yang cukup menguntungkan sehingga prosepek di masa mendatang cukup baik, dan hasil pendapatan yang diterima tersebut cukup mampu memenuhi kebutuhan.

\section{KESIMPULAN}

Dari hasil penelitian dan pembahasan maka dapat ditarik kesimpulan sebagai berikut:

1. Gambaran umum usaha meubel kayu di Kecamatan Arga Makmur

Dari hasil penelitian menunjukkan bahwa rata-rata responden atau pemiliki usaha berusia sekitar3645 taahun dan mampu bekerja pada usaha meubel kayu di Kecamatan Arga Makmur. Kurangnya tingkat pendidikan yang dimiliki oleh para pengelola menjadi hambatan atau kendala dalam pengembangan usaha, karena tingkat pendidikan berpengaruh pada keterampilan pengusaha dalam mengelola dan memproduksi produk yang inovatif untuk menarik konsumen. Mayoritas tingkat pendidikan yang dimiliki usaha meubel kayu Kecamatan Arga Makmur rata-rata adalah lulusan SMA/ Sederajat yaitu sebanyak 27 orang atau sebanyak 90\%. Sedangkan jumlah unit usaha yang telah mereka jalankan mayoritas bekisar antara 5-10 tahun sebanyak 18 unit usaha atau sebesar $60 \%$.

2. Ketenaga kerjaan

Tenaga kerja yang dimiliki oleh tiap unit usaha industry meubel kayu di Kecamatan Arga Makmur rata-rata antara 1-3 tenaga kerja yaitu sebanyak 19 unit usaha atau bekisar $63.3 \%$ dimana tenaga kerja bekerja harian pada usaha tersebut. Maka upah yang diterima pun sesuai dengan berapa hari mereka bekerja dan system upah yang berbeda-beda sesuai dengan pekerjaan yang mereka jalankan. Mayoritas pendidikan tenaga kerja di dominasi oleh tamatan SMA dan SMP. Hubungan dengan penyerapan tenaga kerja, jika dilihat dari hasil penelitian 30 responden diketahui bahwa usaha meubel kayu di Kecamatan Arga Makmur mampu menyerap tenaga kerja kurang lebih sebanyak 100 orang tenaga kerja. Hal ini menunjukan bahwa usaha meubel kayu di Kecamatan Arga Makmur mampu membantu mengurangi tingkat pengangguran dan menciptakan lapangan usaha.

3. Modal

Sumber modal yang diperoleh responden berasal dari modal sendiri sebanyak 26 unit usaha atau sebesar $86.7 \%$. Besarnya modal yang dikeluarkan oleh usaha meubel kayu di Kecamatan Arga Makmur adalah bekisar Rp 10.000.000,- ke bawah. Modal usaha meubel kayu di Kecamatan Arga Makmur ini digunakan sebagai biaya bahan baku produksi, untuk biaya tenaga kerja, dan biaya lainnya. besarnya omset penjualan atau hasil produksi dari usaha meubel kayu di Kecamatan Arga Makmur rata-rata bekisar antara Rp 10.000.000,- s/d Rp 15.000.000,- rata-rata besar pendapatan bersih yang diterima oleh para pengusaha meubel kayu di Kecamatan Arga Makmur yaitu bekisar anatar Rp 2.000.000,0 s/d Rp 3.000.000,- setiap bulannya.

4. Kendala-kendala yang dihadapi oleh usaha meubel kayu yaitu kurangnya tingkat pendidikan pengusaha dan tenaga kerja, kurang sarana dan prasarana pasar, minimnya teknologi yang digunakan.

5. Pengolahan usaha meubel kayu di Kecamatan Arga Makmur masih sederhana. Namun demikian, usaha meubel kayu di Kecamatan Arga Makmur mampu memberikan keuntungan yang baik kepada pengusaha dan mampu meningkatkan pembangunan ekonomi daerah. Peluang usaha akan menjadi lebih baik lagi apabila kendala-kendala yang dihadapi dalam menjalankan usaha mampu diatasi dengan baik. 


\section{SARAN}

Berdasarkan kesimpulan di atas, maka dapat dikemukakan beberapa saran yang kiranya dapat bermanfaat bagi pihak-pihak yang berkepentingan seperti:

1. Usaha meubel kayu di Kecamatan Arga Makmur merupakan salah satu usaha yang cukup baik dan mampu dalam menyerap tenaga kerja, untuk itu diharapkan kepada pemerintah untuk dapat memberikan kebijakan seperti mengadakan pelatihan, studi banding ke usaha yang sudah maju serta menambah berbagai sarana dan prasarana yang dibutuhkan, agar para pengusaha mampu menjalankan usahanya dengan baik sehingga mampu menambahkan lapangan usaha serta meningkatkan ekonomi daerah, selain itu diharapkan juga kepada pemerintah untuk dapat membantu para pengusaha dalam segi permodalan, misalnya saja dengan memberikan bantuan modal atau dengan mempermudah berbagai macam prosedur dalam proses peminjaman kepada lembaga keuangan seperti koperasi dan perbankkan.

2. Diharapkan kepada pengusaha mampu meningkatkan kualitas produksi dan pekerja sehingga mampu meningkatkan kesejahteraan ekonomi bagi perusahaan. Misalnya saja untuk meningkatkan kualitas produksi, pengusaha perlu mengadakan inovasi baru terhadap barang-barang yang diproduksi tanpa harus mengubah kualitas dari bahan baku yang digunakan. Sedangkan untuk meningkatkan kualitas pekerja pengusaha dapat memberikan pendapatan yang baik sesuai dengan yang telah mereka kerjakan.

3. Diharapkan kepada lapisan masyarakat mampu mengawasi dan mengontrol usaha meubel yang berkembang sehingga dapat mencegah pencemaran lingkungan. Selain itu, partisispasi masyarakat dalam mengkonsumsi produk local perlu ditingkatkan sehingga meningkatkan pendapatan daerah.

\section{DAFTAR PUSTAKA}

Arsya, Licolin. 2008. Lembaga Keuangan Mikro, Institusi Kinerja, dan Sustanabilitas. Yogyakarta: CV. Andi Offset.

Badan Pusat Statistik. 2013. Bengkulu Utara Dalam Angka. Bengkulu Utara: BPS.

Badan Pusat Statistik. 2007. Analisis Penyusunan Kinerja Makro Ekonomi dan Sosial Jawa Timur Tahun 2007. BPS Jawa Timur.

Bangun, Wilson. 2010. Teori Ekonomi Mikro. Bandung: PT Refika Aditama.

Daryanto dan Abdullah. 2013. Pengantar Ilmu Manajemen dan Komunikasi. Jakarta: Prestasi Pustakarya.

Frenti Efrimadani. 2010. Skripsi: Analisis Pertumbuhan Lapangan Usaha dan Penyerapan Tenaga Kerja Sektor Industri Formal di Kabupaten Bengkulu Utara Tahun 2006-2010. Bengkulu Utara: Universitas Ratu Samban.

Kasmir. 2011. Kewirausahaan. Jakarta: Rajawali Pers.

Nazir, M. 2003. Ekonomi Sumber Daya Manusia Dalam Perspektif Pembangunan. Jakarta: PT. Raja Grafindo Persada.

Muhlis. 2006. Skripsi: Efisiensi Wilayah Kabupaten/ Kota di Jawa Timur Ditinjau dari Industri Manufaktur Tahun 1998-2001, dan 2004. Jakarta: Sekolah Tinggi Ilmu Statistik.

Rahardja, Prathama, dkk. 2004. Pengantar Ilmu Ekonomi, Makroekonomi dan Mikroekonomi. Jakarta: Fakultas Ekonomi UI.

Santoso, Rokhedi P. 2012. Ekonomi Sumber Daya Manusia dan Ketenagakerjaan. Yogyakarta: UPP STIM YKPN.

Simanjutak, J Payaman. 2005. Manajemen Tenaga Kerja Indonesia, Pendekatan Administratif dan Operasional. Cetakan Ketiga. Jakarta: PT. Bumi Aksara. 
Subandi. 2012. Sistem Ekonomi Indonesia. Bandung: Alfabeta.

Sukirno, Sandono. 2012. Ekonomi Pembangunan: Proses, Masalah dan Dasar Kebijakan. Edisi Kedua. Jakarta: Kencana.

Sumarsono, Sonny. 2009. Teori dan Kebijakan Publik Ekonomi Sumber Daya Manusia. Yogyakarta: Graha Ilmu.

Tarigan, Robinson. 2005. Ekonomi Regional Teori dan Aplikasi, Edisi Revisi. Jakarta: PT. Bumi Aksara.

Teguh, Muhammad. 2010. Ekonomi Industri. Jakarta: Rajawali Pers. 